\title{
Od pisarza narodowego do światowego i z powrotem. O polskich uczestnikach Iowa Writing Program
}

W ciągu ostatnich czterdziestu lat ponad pięćdziesięciu polskich pisarzy wyjechało do Iowa City, by w ramach projektu International Writing Program uczestniczyć w warsztatach kreatywnego pisania, panelach dyskusyjnych, translatoriach i podróżach po najciekawszych zakątkach Ameryki ${ }^{1}$. Polscy twórcy przyjeżdżali do Stanów Zjednoczonych jako laureaci prestiżowych stypendiów przyznawanych im przez Fundacje: Kościuszkowską, Jurzykowskiego i Forda.

${ }^{1} \mathrm{O}$ amerykańskich doświadczeniach stypendystów oraz strukturze i sposobie funkcjonowania samego International Writing Program pisali (oprócz polskich uczestników Programu, wśród których wyliczyć można choćby: Jana Józefa Szczepańskiego, Marka Skwarnickiego, Wacława Sadkowskiego czy Marka Nowakowskiego) Janusz Kaźmierczak i Dorota Kozicka. Kaźmierczak skupił się w swoim artykule na ukazaniu, w jaki sposób podczas zimnej wojny International Writing Program umożliwiał kulturalną i intelektualną wymianę pomiędzy pisarzami z krajów znajdujących się za żelazną kurtyną a twórcami ze Stanów Zjednoczonych i innych państw Zachodu (Kaźmierczak 87-96). Kozicka opublikowała tymczasem tekst o charakterze przeglądowym, w którym - w sposób przyczynkowy - omówiła zainspirowane pobytem w Iowa City dzieła kilku polskich pisarzy, badając na ich przykładzie tożsamość Europejczyków znajdujących się na tymczasowej emigracji z perspektywy postzależnościowej (Kozicka 89-106). Zainteresowanych badaniami nad problematyką tożsamościową w tzw. twórczości pobytowej polskich stypendystów Programu odsyłam ponadto do moich artykułów: Tożsamość odnaleziona w samolocie do San Francisco. Twórcze "ja” w wierszach i pamiętnikach polskich stypendystów International Writing Program, omawiającego pod tym kątem utwory Anny Czekanowicz, Adriany Szymańskiej i Grzegorza Musiała (Moroz 246-254.) oraz Przesztość ukryta „w treściach milczeñ”. Tożsamość polskich emigrantów w ujęciu stypendystów International Writing Program - Leszka Elektorowicza i Julii Hartwig, analizującego dzieła Leszka Elektorowicza i Julii Hartwig (Moroz 191-204). 
Podczas udziału w projekcie uczestniczyli zatem nie tylko w niezliczonej ilości spotkań z amerykańskimi wydawcami, dziennikarzami czy agentami literackimi, ale także w autorskich wieczorach odbywających się w ośrodkach fundacji w Nowym Jorku i Waszyngtonie. Po zakończeniu Programu rekomendowani przez jego organizatorów jeździli po całych Stanach Zjednoczonych, wygłaszając wykłady na renomowanych uniwersytetach. Okoliczności te pozwalały im postrzegać stypendialny wyjazd jako wstęp do błyskotliwej amerykańskiej kariery w stylu Jerzego Kosińskiego. Marzyli o zastąpieniu przypisywanego im dotąd przez krajowe środowisko literackie statusu „pisarza narodowego” mianem „pisarza światowego”. Pomimo wielu starań większości z nich nigdy nie udało się jednak dokonać takiej transformacji. Jak przebiegały próby zmiany wzmiankowanego statusu podejmowane kolejno przez Artura Międzyrzeckiego, Andrzeja Kijowskiego i Grzegorza Musiała?

Andrzej Kijowski przyjechał do Stanów Zjednoczonych w 1972 roku jako uznany polski pisarz, mający w dorobku kilkanaście różnego rodzaju książkowych publikacji, i popularny autor scenariuszy (m.in. Wesela Wajdy). Przed rozpoczęciem programu stypendialnego występował w Nowym Jorku i Waszyngtonie jako gość spotkań literackich cieszących się dużym zainteresowaniem w środowisku amerykańskich twórców (jak wspomina sam autor, jego występ był później szeroko komentowany, a jego echa dotarły nawet do Kalifornii [Kijowski 165]). Podczas pobytu w Iowa poświęcał się intensywnej pracy literackiej (pisał jednocześnie dwie powieści, z których jedna opowiadać miała nową wersję lokalnej legendy o poszukiwaniu Ameryki przez św. Brendana) i uczestniczył w przyjęciach organizowanych zarówno przez członków amerykańskiej bohemy, jak i przez protektorów Programu. W tym samym czasie aktywnie współpracował także z rodzimymi periodykami literackimi, przygotowując serię felietonów o amerykańskich twórcach dla Tygodnika Powszechnego oraz krytyczne szkice dla Dialogu i został uhonorowany prestiżową londyńską nagrodą im. Anny Godlewskiej. Jak to możliwe, że mimo tak wielu starań pisarzowi nie udało się zdobyć światowego literackiego rozgłosu?

Analizując przypadek Andrzeja Kijowskiego, należy pamiętać, że podczas pobytu w Stanach twórca nieustannie zmagał się z barierą językową. To, że nie operował językiem angielskim nawet w podstawowym stopniu, sprawiało, iż nie tylko nie był w stanie nadążyć za innymi polskimi stypendystami, którzy 
redagowali anglojęzyczne antologie europejskich poetów i publikowali własne przekłady wierszy wybitnych, acz nieznanych jeszcze Amerykanom polskich autorów, ale nie mógł nawet odpowiednio wykorzystać nadarzających się sposobności do nawiązania kontaktów z amerykańskimi wydawcami czy agentami literackimi. W liście do żony z dwudziestego listopada 1972 roku wyznał:

Między mną a zewnętrznym światem wciąż rozciąga się screen (ekran, siatka, zasłona) niezrozumiałości. Nic nie rozumiem. Nie rozumiem dialogów w kinie, komentarzy telewizyjnych, komunikatów radiowych ani tego, co do mnie ludzie mówią - i to jest najokropniejsze (200-201).

Odczuwane przez twórcę kompleksy, wynikające z niemożności uczestniczenia w intelektualnych konwersacjach, jakie prowadzili między sobą stypendyści, pogłębiły ponadto jego skłonność do malkontenctwa i introwertyzmu. Jeszcze przed przyjazdem do Iowa Kijowski dał się poznać jako wiecznie niezadowolony, znerwicowany uczestnik międzynarodowych programów stypendialnych. Jak odnotowała Katarzyna Wiśniewska, autorka upamiętniającego sylwetkę pisarza szkicu pt. Tak pięknie, że strach:

W 1960 r. Kijowski wyjeżdża do Paryża na stypendium Fundacji Forda. Tam też jest ciągle niezadowolony [...]. Napisze potem, że paryskie przeżycia niejednemu starczyłyby na samobójstwo. [...] Czasami zamiast nazwy miasta widnieje „Dno” albo „Czyściec”. [...] Postanowił nauczyć się współczesnej filozofii [ale] przedzieranie się przez hermetyczne teksty frustrowało go. Kina nudziły. Hałas za oknem przyprawiał o zawrót głowy (Wiśniewska 25).

Fragmenty listów Kijowskiego dotyczące jego udziału w International Writing Program obfitowały w podobne refleksje. Pisarz nazwał w nich Iowa City melancholijnym miejscem (Kijowski 192), w którym najdrobniejsze zmartwienie urasta do rangi dramatu (194), a sam Program określił jako „bezsensowną imprezę” (167) i „komedię, rozgrywającą się na jego oczach” (202). Wyznał, że pragnąc oszczędzić sobie dalszych językowych mąk, celowo unika spotkań z innymi stypendystami:

Chowam się przed ludźmi, co musi sprawiać okropne wrażenie. Ponieważ to muszę robić w jakimś stylu, robię to wyniośle, i wychodzę na pyszałka (201). 
Przyznał się także do zatajenia informacji o otrzymaniu międzynarodowej nagrody literackiej, tłumacząc, że jej rozpowszechnienie pociągnęłoby za sobą przykrą konieczność świętowania sukcesu razem z „kolegami” z Programu.

Nieprzekraczalna - z punktu widzenia Kijowskiego - bariera językowa i przyjmowana przez niego aspołeczna postawa z pewnością nie przysporzyły mu popularności w międzynarodowym środowisku literackim. Podstawowym czynnikiem uniemożliwiającym twórcy osiągnięcie pożądanego statusu pisarza światowego był jednak - jak mi się wydaje - kulturowy aspekt owego przedsięwzięcia. W Dziennikach Kijowskiego Ameryka etykietowana jest jako obcy ląd od dawna zamknięty dla przybyszów z innych kontynentów. Ląd, który kusi odbijającą się na niebie łuną dalekich świateł wielkiego miasta, przyciąga i mami szumem oceanu, lecz jednocześnie odgradza się od reszty świata wielkimi płotami i tabliczkami z napisem private. Obserwacje poczynione przez pisarza w czasie trwania Programu prowadzą do gorzkiej konstatacji, że Amerykanów tak naprawdę nie interesuje twórczość reprezentantów innych kultur. Na początku Kijowskiego drażniła powierzchowność okazywanego mu przez nich zainteresowania. Złościła pobieżność, z jaką organizatorzy Programu przygotowali biogramy swoich gości, skracając do minimum długie listy ich publikacji i osiągnięć. Przeszkadzała anonimowość, od której - jak pisał - zdążył już odwyknąć (Kijowski 194-195). W końcu doszedł jednak do wniosku, że Amerykanie nie są po prostu w stanie odpowiednio ocenić wartości znacznej części stworzonych przez stypendystów dzieł, gdyż jest ona dla nich nieweryfikowalna. Stwierdził:

Każdy z nas z osobna jest [...] bardzo wartościowym człowiekiem, ale wartość jego sprawdza się gdzie indziej - w jego języku, w jego kulturze, pośród jego czytelników i krytyków. [...] Każdy z nas miał kartkę na piersiach z nazwiskiem, które tu nic nie znaczyło, i coś w zanadrzu, co też nic nie znaczyło (199).

Przytłoczony nieprzekładalnością języków dwóch zupełnie odrębnych kultur, o której znaczeniu z całą mocą przekonał się dopiero w Ameryce, Kijowski wycofał się, rezygnując z dalszych starań o literackie zaistnienie na gruncie amerykańskim.

Zupełnie inną postawę przyjął Grzegorz Musiał - stypendysta, który przyjechał do Iowa City w 1988 roku jako autor trzech powieści i tomu przekładów wierszy Allena Ginsberga oraz laureat kilku prestiżowych nagród literackich (m.in. im. Stanisława Piętaka i Wyspiańskiego). Od pierwszego dnia 
pobytu w Ameryce pisarz prowadził dziennik, w którym krytykował sposób funkcjonowania Programu, wyśmiewał założenia przyświecające jego twórcom i z ironią komentował nadzieje na zdobycie międzynarodowej sławy, jakimi inni stypendyści okraszali swoje wysiłki. W rzeczywistości była to jednak tylko literacka kreacja. Maska, pod którą starał się ukryć towarzyszące mu ambicje. Od początku Musiał wykazywał bowiem wielkie zaangażowanie w rozwój swej literackiej kariery. Jako tłumacz doskonale operujący językiem angielskim przekładał własne wiersze i publikował je w amerykańskich czasopismach, takich jak: „Poetry East, Poetry World” czy „Artful Dodge” oraz antologiach (m.in. w Walter Cummins Shifting Borders. East European Poetries of the Eighties). Współpracował z amerykańskim poetą i tłumaczem Danielem Weissbortem, przygotowując anglojęzyczne wydanie tomu z poezją Mirona Białoszewskiego oraz antologię z przekładami wierszy współczesnych amerykańskich poetów na język polski pt. Ameryka, Ameryka! Antologia wierszy poetów amerykańskich po 1940 roku. Przeprowadził głośny wywiad z Josifem Brodskim, a publikacją plonu tej rozmowy zainteresowały się zarówno polskie czasopisma, jak i prestiżowe uniwersyteckie wydawnictwo Oxford University Press. Wreszcie, starał się wykorzystać zawarte w Stanach znajomości, by ogłosić tam wybór swoich wierszy, i choć początkowo nie udało mu się tego dokonać, bo jedyne zainteresowane wydawnictwo odrzuciło manuskrypt, po kilku latach książka została w końcu wydana przez oficynę Fairleigh \& Dickinson z Baltimore. Gdy zaś semestr stypendialny International Writing Program zbliżał się do końca, Musiał postarał się o jego wydłużenie, dzięki czemu udało mu się spędzić w Iowa City aż dwa lata. W tym czasie wielokrotnie spotykał się z profesorami wykładającymi literaturę na amerykańskich uniwersytetach, wydawcami i pisarzami światowej sławy, takimi jak John Ashbery czy Allen Ginsberg. Wszystkie te działania okazały się jednak niewystarczające do zapewnienia Musiałowi statusu światowego pisarza. Rozczarowany, analizował przyczyny swego niepowodzenia, upatrując najpierw jego źródła w fascynacji Amerykanów nowoczesną technologią i obrazem, który - zdaniem twórcy - niemal wyparł w ich kraju słowo pisane. Sfrustrowany poczynioną obserwacją, pytał samego siebie:

Po co więc do Ojczyzny Obrazu, która wynalazła te migotania, przyjeżdżać ze słowami? Z jakimiś maszynopisami, w których są nasze i tylko nasze sny, lęki, chorobliwe stany ducha $[\ldots]$, namiętności, opisy naszych odcisków [...] 
mieszkania w prowincjonalnych miasteczkach Słowacji, Finlandii czy Konga, jakieś zapomniane szkolne miłości w Indiach czy Drohobyczu... Kogo to obchodzi, kto ich tu potrzebuje? (Musiał 9-10).

Jego diagnozę potwierdził Alan Lefcowitz - poeta, prowadzący Ośrodek dla Pisarzy w Betsheda pod Waszyngtonem, który podczas spotkania ze stypendystami stwierdził:

Tylko obraz [...] jest w stanie dotrzymać kroku szalonym cyberczasom, które idą! Dłubanina w słowie, w jakichś stylach, formach - to hobby zdziwaczałych profesorów. Młodzi chcą pisma obrazkowego i je dostaną! (Musiał 81).

Zastanawiając się nad czynnikami, które sprawiły, iż pomimo owej niekwestionowanej - w jego odczuciu - dominacji obrazu nad słowem, niektórym pisarzom udało się jednak zrobić w Ameryce karierę, Musiał doszedł do wniosku, że szczególne zainteresowanie wzbudzają tam ci twórcy, którym towarzyszy aura sensacji i skandalu. Konstatację tę opatrzył cynicznym komentarzem:

[Tu] trzeba nie pić, a chlać, szprycować się w eleganckim towarzystwie, być homoseksualistą walczącym o prawa gay'ów, nie cierpieć Kościoła katolickiego i na koniec popełnić samobójstwo na Manhattanie albo przynajmniej umrzeć na AIDS. To jeśli chodzi o Amerykanów - bo przyjezdni w ogóle są bez szans, jeśli nie przywieźli ze sobą Nobla [i] nie przesiedzieli pół życia w sowieckim łagrze (22-23).

W odniesieniu do tego spostrzeżenia opisał swoje spotkanie ze znajomym wydawcą, który z całą powagą sugerował mu, by ten skontaktował się z popularnym amerykańskim baseballistą o nazwisku Stan Musial i zaproponował, że będzie udawał jego odnalezionego po latach syna albo przynajmniej kuzyna-poetę z Europy. Jak przekonywał wydawca, umieszczenie takiej informacji na obwolucie tomiku z wierszami poety znacznie zwiększyłoby jego poczytność. Kontynuując swoje obserwacje i rozważania nad recepcją literatury w Stanach Zjednoczonych, twórca wysunął ponadto wniosek, że najlepiej sprzedają się tam produkowane taśmowo romanse, a o popularności danego autora czy autorki decydują gospodynie domowe, które - traktując książki na równi z innymi towarami - wrzucają do kosza pełnego zup najnowszą powieść Danielle Steel czy Judith Krantz, ponieważ ich stos ustawiono akurat na kilka dni przy kasie obok gum do żucia. 
Od krytyki literatury masowej Musiał przeszedł płynnie do wykpiwania amerykańskiej poezji, nieprzystającej w jego odczuciu do, filozoficznej i osadzonej głęboko w historii oraz kulturze, twórczości polskich poetów. Porównując obie poetyki, pisał:

[Amerykanie] się gubią wśród znaków i wśród instrukcji, jak się ze znakami obchodzić. Nawieźli tu tego z Europy, ale im się po drodze rozsypało. I siedzą nad kupą znaków, archetypów, symboli, dłubią w tym z wielką powagą i biorą je jeden po drugim, oglądając pod światło jak śmieciarka butelki, i piszą, piszą... Gdy jeden ironiczny, stary jak Europa wers Szymborskiej, jeden zakrętas Miłosza, jedna metafora Herberta - jak różdżka mistrza wprawia to wszystko w uporządkowany ruch (207-208).

Krytykował też wypracowaną przez Beat Generation technikę poetycką, którą określał mianem „przepisywania własnych myśli jak komputer” (175). Współczesną Amerykę nazywał zaś „Wielką Kulturą Niższą” i podkreślał, że przyjeżdżający do niej europejscy pisarze są reprezentantami kultur wyższych, którzy dla kariery zdecydowali się po prostu zaprzedać duszę diabłu (100-101).

Wszystkie te konstatacje wprawiły pisarza w dojmujące poczucie bezradności. Przybywając do Stanów jako autor świeżo wydanej skandalizującej powieści W ptaszarni, która - jak w swojej recenzji podkreślał Zbigniew Masternak - choć znakomita, została przemilczana przez pruderyjne polskie społeczeństwo, gdyż opowiadała o losach bohaterów wykluczonych z polskiej tożsamości zbiorowej i zawierała odważne opisy erotycznych aktów i fantazji (Masternak 73-77), Musiał żywił nadzieję, że znajdzie dla siebie miejsce w „Ojczyźnie Wolności” (jak nazywał Amerykę). Ojczyzna Wolności okazała się jednak Ojczyzną Obrazu, a oferowany przez pisarza literacki skandal zbyt mało - jak na Amerykę - skandaliczny. Z jednej strony Musiał świadom był faktu, iż zarówno jego wiersze, konsekwentnie wyzyskujące homoerotyczną tematykę, jak i powieść, napisana mało przystępnym stylem i pełna aluzji literackich nieuchwytnych dla przeciętnego czytelnika, nie zainteresują odbiorców literatury masowej, którzy zakupów książkowych dokonywali we wzmiankowanych supermarketach. Z drugiej - nie chciał bądź nie potrafił stworzyć wokół siebie tak pożądanej atmosfery skandalu. Jak stwierdził z goryczą: 
[Trzeba było] dobrać sobie orkiestrę z bębnów, fagotów, waltorni [...] i piąć się z tym wrzaskiem w górę! [...] Na szczyt! Z harfą! Z czynelami! Z chórem światowych feministek i orkiestrą gayów! [...] Z limuzynką [...] Z „wydawcami!” (Musiał 187).

Owa „pośredniość” lokująca Musiała „gdzieś pomiędzy” i brak chóru, który mógłby wzmagać zbyt słaby (jak na amerykańskie ucho) tembr jego głosu, sprawiły, że pisarz nie został zauważony przez zagranicznych krytyków. Zapomnieli o nim także rodzimi twórcy i badacze, którzy w tym samym czasie prowadzili na łamach Tygodnika Powszechnego dyskusje o minionej dekadzie w literaturze polskiej ${ }^{2}$. Polskim attaché kulturalnym w Waszyngotnie została zaś Agnieszka Osiecka, chociaż to Musiał parę miesięcy wcześniej otrzymał stypendium waszyngtońskiej fundacji.

Być może pewien wpływ na odbiór Musiała jako twórcy miało również to, iż pisanie było dla niego przede wszystkim pasją, podczas gdy zawodowo zajmował się okulistyką. Lekarz, w wolnych chwilach pisujący wiersze, mógł być przez środowisko literackie postrzegany jako pisarz amator i wyłączany z grona twórców profesjonalnych, dla których pisanie było zwykle jedynym uprawianym zawodem. Przypuszczenie to zdaje się potwierdzać zabawna anegdota o wizycie autora w domu Alana Lefcowitza - dyrektora Ośrodka dla Pisarzy pod Waszyngtonem. Jak wspominał Musiał:

[żona Lefcowitza] zaraz siadła obok mnie i zaczęła zaglądać mi w twarz szkłami grubymi jak dna od butelek. W końcu zacząłem niespokojnie się ruszać - czyżby moja sława dotarła już za Ocean? A ona nic, gapi się, i dopiero zbliżywszy oczy tak blisko, że poczułem w nosie łaskotanie jej piórek przy kołnierzu, spostrzegła, że ruszam się niespokojnie. - To ty jesteś tym okulistą? - padło jej niepozostawiające żadnych złudzeń pytanie (80).

Najbardziej zastanawiający jest jednak w moim odczuciu przypadek Artura Międzyrzeckiego. Przyjechał on do Iowa City w 1970 roku wraz ze swoją żoną Julią Hartwig (także stypendystka) i córką Danielą jako jeden z pierwszych polskich pisarzy zaproszonych do udziału w International Writing Program. Był już wówczas uznanym twórcą, posiadającym w dorobku ponad trzydzieści

${ }^{2}$ Mam tu na myśli dyskusję pomiędzy Jerzym Pilchem a Janem Błońskim, Tadeuszem Nyczkiem, Jerzym Jarzębskim i Marianem Stalą (Pilch 1, 4-5.) oraz ripostę Szarugi (Szaruga 8). 
książkowych publikacji, wśród których znalazły się zarówno wybory poezji, piosenek czy opowiadań, jak i szkice krytyczne, opracowania i przekłady. Należał także do wielu literackich stowarzyszeń i zespołów redakcyjnych zagranicznych czasopism, takich jak L'Astrado. Powszechna w PRL-u cenzura blokowała jednak jego kolejne publikacje. Jak z rozżaleniem zanotował w dzienniku: „Na jakiś czas nie nadaję się do druku, tak postanowiono w którymś miejscu miarodajnym” (Międzyrzecki 326). Wyjazd do Ameryki jawił się zatem pisarzowi jako jedyna w swoim rodzaju okazja do przemówienia własnym głosem.

Wkrótce po rozpoczęciu Programu Międzyrzecki zawarł przyjazne stosunki z jego dyrektorem. Paul Engle pomógł mu w zdobyciu posady wykładowcy State University of Iowa, dzięki czemu pisarzowi i jego rodzinie udało się pozostać w Stanach aż przez cztery lata. W tym czasie Międzyrzecki prowadził także wykłady na uniwersytetach w Des Moines i w Stony Brook. Był gościem wielu autorskich wieczorów (w swoich Dziennikach wspominał m.in. wieczorek swój i Julii Hartwig w nowojorskim PEN Clubie, podczas którego głos zabierali Allen Ginsberg i Jerzy Kosiński). Spotykał się również z wybitnymi amerykańskimi twórcami, takimi jak Susan Sontag. W 1972 roku wysiłki pisarza zwieńczone zostały publikacją tomu jego wierszy w języku angielskim (14 poems) przez iowańskie wydawnictwo The Windhover Press. Długi pobyt w Stanach, anglojęzyczna publikacja, posada wykładowcy na amerykańskich katedrach i wieloletnie przyjaźnie ze światowej sławy pisarzami, jakie Międzyrzecki nawiązywał dzięki swej niebywałej towarzyskiej otwartości, szybko wzbudziły zazdrość innych polskich stypendystów, niemogących poszczycić się podobnymi sukcesami. Kijowski z ironią opisywał w dzienniku „zachłyśnięcie się” Międzyrzeckiego jego amerykańskim życiem oraz dumę pisarza z domu, który nie był nawet jego własnością (Kijowski 193), Musiał nazywał go „profesorem, który z ambony wzniesionej z puszek po piwie, z rachunków za domek, [trawnik i futro żony] grzmi, prawi i wie lepiej” (Musiał 48). Ostatecznie owe ukłucia zazdrości okazały się bezpodstawne, gdyż Międzyrzeckiemu nie udało się uzyskać miana pisarza światowej sławy. Trudno dziś jednak orzec, dlaczego tak się stało. Można przypuszczać, że przeszkodziła mu odczuwana przez niego presja i zdobyte wraz z przeprowadzką nowe spojrzenie na rzeczywistość, którego - pomimo starań - nie potrafił oddać w swojej twórczości. Tak mógłby bowiem sugerować dokonany przez niego następujący zapis w dzienniku: 
Co zyskałem [...]? Jednak inną perspektywę. Myśmy właściwie jeździli z Warszawy do Paryża jakby z Polszy po Powstaniu Styczniowym (albo Październikowym) do Stolicy Drugiego Cesarstwa. [...] Myślę, że to doświadczenie paroletnie dużo w moim życiu zmieniło i przemeblowało. Również dlatego marnie mi się pisze, chciałoby się zacząć wszystko od nowa (Międzyrzecki 318).

Być może obawiał się, że jeśli przyjmie w swoich wierszach nową perspektywę, jego poezja stanie się podobna twórczości współczesnych amerykańskich poetów, którą darzył pewnym uznaniem, lecz uważał za magię w gruncie rzeczy nieskuteczną, bo oderwaną od przedmiotu swoich zainteresowań. Jak podkreślał:

w Polsce zbawia nas ekran historyczny [...] i boleść i rozpacz jest obywatelska, wpisana w historię. Tutaj - nie. Ginie się bez odwołań do czegokolwiek - i nie patrzy współczujące oko dziejów. Wskutek czego czepiają się natury. [...] Mój Boże, przecież tu jest tampon naiwnych (308).

Być może jednak do jego niepowodzenia przyczyniło się to, że pisarz unikał tak pomocnych w promocji skandali (o których - nie bez pewnej dozy słuszności - pisał Musiał, a na które zwracał uwagę również sam Międzyrzecki, opisując m.in. przebieg amerykańskiej kariery Kosińskiego i Ginsberga). Możliwe zaś w końcu, że twórca, nękany nostalgią, o której zarówno on sam, jak i jego żona rozpisywali się w pamiętnikach i listach do zaprzyjaźnionych polskich pisarzy, powrócił ze Stanów zbyt szybko, by zdążyć nadać swej zagranicznej karierze odpowiedni impet.

Polscy stypendyści przyjeżdżali do Iowa City zrealizować swój pisarski american dream. Pragnęli wtopić się w grupę sławnych światowych twórców i stać się jej nieodłączną częścią. Pomimo wielu starań żadnemu z nich nie udało się jednak tego osiągnąć. Wieloaspektowość problemu nastręcza trudności we wskazaniu konkretnych przyczyn owego niepowodzenia. Analizując poczynione przez autorów wyznania i spostrzeżenia utrwalone w dziennikach i listach do bliskich im osób, nie sposób jednak oprzeć się wrażeniu, że transformację w „światowych pisarzy” uniemożliwiało im przede wszystkim zbyt silne osadzenie we własnej kulturowej i narodowej tożsamości. Przybywający do Stanów stypendyści próbowali żyć tak jak Amerykanie. Chłonęli piękno szczególnie bliskich im krajobrazów, starali się zgłębiać różnorodne manifestacje ich kultury, odwiedzając muzea i filharmonie, uczestniczyli w tych samych co 
oni spotkaniach literackich, uniwersyteckich dyskusjach i przyjęciach w mieszkaniach amerykańskiej bohemy. Mentalnie pozostawali jednak twórcami z Polski, żyjącymi sprawami swojego kraju, opatrującymi utwory nieodłącznym ekranem historycznym, pełnymi własnych nostalgii i refleksji, których Amerykanie nie byli w stanie zrozumieć. Podobnie jak we własnym kraju, gdzie mianem „pisarzy narodowych” określało ich głównie środowisko literackie, a nie tłumy wielbicieli i czytelników, ostatecznie przypadała im więc jedynie rola tymczasowych satelitów, świecących światłem odbitym od większych i bardziej wyrazistych literackich „gwiazd”.

\section{Bibliografia}

Kaźmierczak, Janusz. „The University of Iowa International Writing Program as a vehicle of East-West cultural exchange". Polish-Anglosaxon Studies 16 (2013): 87-96.

Kijowski, Andrzej. Dziennik 1970-1977. Kraków: Wydawnictwo Literackie, 1988.

Kozicka, Dorota. „My zdies’ emigranty? Polski pisarz w „podróży służbowej”. Narracje migracyjne w literaturze polskiej XX i XXI wieku. T. 2. Red. H. Gosk. Kraków: Universitas, 2012. 89-106.

Masternak, Zbigniew. „Rozpaczliwy topot skrzydeł”. Akcent 1-2 (2001): 73-77.

Międzyrzecki, Artur. To samo miasto, ta sama mitość. Warszawa: Czytelnik, 1992.

Moroz, Agnieszka. „Tożsamość odnaleziona w samolocie do San Francisco. Twórcze «ja» w wierszach i pamiętnikach polskich stypendystów International Writing Program”. Literatura polska w świecie. T. 5. Mapowanie, opisy, interpretacje. Red. R. Cudak. Katowice: Wydawnictwo Gnome, 2014. 246-254.

---. „Przeszłość ukryta «w treściach milczeń». Tożsamość polskich emigrantów w ujęciu stypendystów International Writing Program - Leszka Elektorowicza i Julii Hartwig”. Interferencje Kultury Wspótczesnej. Red. A. Górajek, A. Jagłowska, D. Wyrzykiewicz. Warszawa: Zakład Graficzny Uniwersytetu Warszawskiego, 2015. 191-204.

Musiał, Grzegorz. Dziennik z Iowa. Zapiski z Ameryki. Poznań: Zysk i s-ka, 2007.

Pilch, Jerzy. „Czarna dziura lat osiemdziesiątych”. Tygodnik Powszechny 13 (1990): 1, 4-5. 
Szaruga, Leszek. „Obok literatury (Spór o «czarną dziurę lat osiemdziesiątych»)”. Tygodnik Powszechny 18 (1990): 8.

Wiśniewska, Katarzyna. „Tak pięknie, że strach”. Gazeta Wyborcza (Warszawa) 158 (2005): 24-26.

\title{
From the National Writer to the Global One and Back Again: Polish Participants of the Iowa Writing Program
}

\begin{abstract}
Summary
Since 1966 Polish authors regularly participate in the world-famous International Writing Program at the University of Iowa in Iowa City, USA. Selected writers arrive in the United States as recipients of prestigious grants in order to meet American publishers, literary agents, journalists and readers. During their residency they establish relationships with other recognized writers and representatives of the world's intellectual elite. Recommended by the Program's organizers, they give lectures at renowned American universities after their residency in Iowa comes to an end. Due to these circumstances, they often perceive their stay in the US as an opportunity to upgrade their status of a national writer to the global one. Nevertheless, most of them do not succeed in such a transformation.

The paper traces the efforts of three Polish writers: Andrzej Kijowski, Grzegorz Musiał and Artur Międzyrzecki, undertaken with the hope of making an international career. It also tries to find an explanation for their failure in this respect and to show how the lack of meaningful success outside Poland influenced the way in which these writers treated world literature and its representatives.
\end{abstract}

Keywords: the national writer, the global writer, literary fame, Polish literature, American literature, Andrzej Kijowski, Artur Międzyrzecki, Grzegorz Musiał

Słowa kluczowe: pisarz narodowy, pisarz światowy, sława literacka, literatura polska, literatura amerykańska, Andrzej Kijowski, Artur Międzyrzecki, Grzegorz Musiał 